\title{
Free-to-Total Leptin Ratio in Maternal Plasma is Constant Throughout Human Pregnancy
}

\author{
Mercy A. NUAmah, Norimasa SAGAWA, Shigeo YURA, Hiroko MiSE, HiroAKi ITOH, \\ YOSHIHIRO OGAWA* , KAZUWA NAKAO* AND SHINGO FUJII \\ Department of Gynecology and Obstetrics, Kyoto University Graduate School of Medicine, 54 Shogoin Kawahara-cho, Sakyo-ku, \\ Kyoto 606-8507, Japan \\ *Department of Medicine and Clinical Science, Kyoto University Graduate School of Medicine, 54 Shogoin Kawahara-cho, \\ Sakyo-ku, Kyoto 606-8507, Japan
}

\begin{abstract}
To clarify the mechanism of leptin resistance during pregnancy, we measured plasma leptin concentrations, free to total leptin ratio (percent free leptin) and soluble leptin receptor concentrations in pregnant women, and compared the results with those in non-pregnant women. We collected plasma samples from 23 non-pregnant and 31 pregnant women in the third trimester. Plasma samples from 5 pregnant women were collected longitudinally in each trimester. Plasma leptin concentrations in pregnant women in the second trimester $(17.4 \pm 3.2 \mathrm{ng} / \mathrm{ml})$ were higher than those in the first trimester of pregnancy $(11.0 \pm 2.8 \mathrm{ng} / \mathrm{ml}, \mathrm{n}=5)$, as previously reported. However, percent free leptin did not change significantly throughout pregnancy. Percent free leptin correlated with total leptin concentrations (ng/ml) in non-pregnant women $(\mathrm{r}=0.727, P<0.0001)$, but not in women in the third trimester of pregnancy $(\mathrm{r}=0.006)$. Constant percent free leptin during pregnancy despite increased leptin concentrations indicates increased leptin binding capacity in pregnant women, that might partly contribute to the establishment of leptin resistance. On the other hand, soluble leptin receptor concentrations showed significant negative correlation with BMI and plasma leptin concentrations in pregnant women $(\mathrm{r}=-0.470, \mathrm{P}<0.01$ and $\mathrm{r}=-0.493, \mathrm{P}<0.01$, respectively) but not in non-pregnant women. These data suggest the possibility that soluble leptin receptor is a minor component of leptin binding capacity in the plasma of pregnant women.
\end{abstract}

Key words: Pregnancy, Percent free leptin, Soluble leptin receptor

(Endocrine Journal 50: 421-428, 2003)

ENERGY requirement increases in pregnancy to support the growing fetus, and to prepare the mother for nursing thereafter $[1,2]$. As energy intake increases, the glucose metabolism alters with hyperlipidemia usually observed in pregnant women. Leptin is a peptide hormone that suppresses food intake and works as a local mediator for glucose and lipid metabolism [3, 4]. It is abundantly produced by adipose tissue, leading to elevated plasma leptin concentrations in obese persons [5]. As a result, plasma leptin concentrations

Received: June 20, 2002

Accepted: April 11, 2003

Correspondence to: Norimasa SAGAWA, M.D., Ph.D., Department of Gynecology and Obstetrics, Kyoto University Graduate School of Medicine, 54 Shogoin Kawahara-cho, Sakyo-ku, Kyoto 606-8507, Japan are well correlated with body fat mass and with body mass index (BMI) [6, 7]. However, appetite is not suppressed in obese persons, hence leptin resistance in such persons has been proposed.

We previously reported that leptin is also produced by placental trophoblasts and secreted into both maternal and fetal circulations, leading to increased maternal plasma leptin concentrations during pregnancy $[8$, 9]. Linnemann et al. reported that $98.4 \%$ of placental leptin is secreted into maternal circulation and $1.6 \%$ into the fetal circulation [10]. This is in accordance with our report that leptin levels in maternal peripheral veins were significantly higher than those in both umbilical arteries and veins [9]. Maternal plasma leptin concentrations rise 2- to 3-fold during pregnancy and rapidly decline after removal of the placenta, suggesting that the placenta is the major contributor to hyper- 
leptinemia during pregnancy.

In order to understand the biological roles of leptin as a regulator of energy metabolism during gestation, it is important to clarify the mechanism for leptin resistance in pregnant women. It is reported that leptin binds to some circulating proteins, which may alter its bioactivity, transport and/or clearance [11, 12]. Free leptin is considered biologically active because bound leptin does not reach the hypothalamus, the main site of leptin function. In obese persons, however, leptin binding protein is not likely a major factor of leptin resistance, since the free leptin to total leptin ratio is increased $[11,12]$. On the other hand, the role of leptin binding protein in the plasma of pregnant women has yet to be clarified.

The present study was designed to elucidate the mechanism of leptin resistance during pregnancy. To determine the availability of leptin to its center of action in the hypothalamus, we measured percent free leptin in the maternal plasma using both cross sectional and longitudinal studies. Soluble leptin receptor is considered to be one of the key leptin binding proteins in humans and rodents. In mice the soluble leptin receptor is secreted by the placenta, resulting in marked rise of plasma leptin concentrations and thus contributing to the establishment of leptin resistance during pregnancy [13]. In addition to soluble leptin receptor, several leptin binding proteins have been identified, such as the protease inhibitor $\alpha 2$-macroglobulin in human plasma [14], OB-BP1/Siglec-6, OB-BP2/Siglec5 , and CDC33/Siglec-3, which are the sialic-acid binding lectins of the immunoglobulin superfamily [15]. However, the characteristics of leptin binding proteins have yet to be fully clarified. Therefore, we also examined the circulating soluble leptin receptor concentrations in non-pregnant and pregnant women.

\section{Subjects and Methods}

\section{Subjects}

Twenty-three non-pregnant women and 31 pregnant women were included in the study. None of these women had diabetes mellitus, hypertension, preeclampsia or any other neuroendocrine diseases before or during pregnancy. Informed consent was obtained from each participant before enrolling in the study. The study was approved by the ethical committee on human research of Kyoto University Graduate School of Medicine.

Plasma samples were collected from 31 pregnant women in the third trimester (35-37 weeks) of gestation. Plasma samples obtained from 23 non-pregnant women were used as control. Clinical data of these patients are summarized in Table 1. For 5 women (mean age $31.2 \pm 10$ years) among the 31 pregnant women, plasma samples were also collected in the first $(8-12$ weeks gestation) and second trimester (28-32 weeks gestation). Body weights of the 5 women before pregnancy and at each trimester were $48.2 \pm 2.0,48.9$ $\pm 2.5,54.5 \pm 1.6$ and $56.7 \pm 2.1 \mathrm{~kg}$ respectively. Their BMI were $19.1 \pm 0.6,19.4 \pm 0.8,21.7 \pm 0.5$ and 22.3 $\pm 0.6 \mathrm{~kg} / \mathrm{m}^{2}$, respectively.

\section{Plasma sampling}

Blood samples were drawn from the antecubital vein and were transferred immediately to chilled siliconized glass tubes containing sodium ethylenediamine-tetraacetatic acid $\left(\mathrm{Na}_{2}\right.$ EDTA) $(1 \mathrm{mg} / \mathrm{ml})$ and aprotinin $(1,000$ units $/ \mathrm{ml})$, and centrifuged at $3,000 \times \mathrm{g}$ for $5 \mathrm{~min}$ at $4^{\circ} \mathrm{C}$. Plasma samples thus obtained were stored at $-20^{\circ} \mathrm{C}$ until use.

Table 1. Clinical data of non-pregnant and pregnant women.

\begin{tabular}{lcc}
\hline Parameter & Non-pregnant $(\mathrm{n}=23)$ & Pregnant $(35-37$ weeks $)(\mathrm{n}=31)$ \\
\hline Age $(\mathrm{yr})$ & $34.5 \pm 2.3(22-48)$ & $31.6 \pm 0.7(19-39)$ \\
Body weight before pregnancy $(\mathrm{kg})$ & - & $56.8 \pm 1.6(41.8-81.4)$ \\
Body weight at sampling $(\mathrm{kg})$ & $54.2 \pm 1.3(33-68.6)$ & $66.7 \pm 1.9(51-95.7)$ \\
Body mass index $(\mathrm{BMI})\left(\mathrm{kg} / \mathrm{m}^{2}\right)$ & $21.9 \pm 0.6(16.9-27.8)$ & $25.7 \pm 0.6(20.69-30.67)$ \\
Gestational age $(\mathrm{wk})$ & - & $35.7 \pm 0.1(35-37)$ \\
Gestational weight gain $(\mathrm{kg})$ & - & $9.8 \pm 0.5(3.9-18.4)$ \\
\hline
\end{tabular}

Values are mean \pm SEM (range) 


\section{Determination of plasma leptin concentrations}

Human leptin concentrations in plasma samples were determined by radioimmunoassay (RIA) for human leptin as previously reported $[8,9,16]$. The detection limit of this assay was $0.05 \mathrm{ng} /$ tube. Inter- and intra-assay variations were $5.9 \%$ and $5.3 \%$, respectively [16].

\section{Separation of free and bound leptin}

To separate free leptin from bound leptin, we fractionated plasma samples $(200 \mu \mathrm{l})$ on Sephacryl S-200 gel filtration column with phosphate buffered saline (PBS), containing $0.01 \%$ sodium azide $\left(\mathrm{NaN}_{3}\right)$. The elution position of the void volume and free leptin was determined by loading blue dextran and recombinant leptin, respectively. Leptin concentration in each fraction was determined by RIA [16] or high sensitivity ELISA (Shionogi Pharmaceutical Co., Osaka, Japan) according to manufacturer's recommendation [17]. Because leptin concentrations in fractionated samples were too low to be measured by RIA, each fraction $(500 \mu \mathrm{l})$ was freeze-dried and reconstituted with $125 \mu$ l of RIA buffer before assay.

We also employed an alternative method to calculate the leptin binding capacity in the plasma as previously reported [18] with slight modification. We incubated plasma with ${ }^{125} \mathrm{I}$ labeled leptin $(\sim 5,000 \mathrm{cpm}$, specific activity was $0.11 \mathrm{mCi} / \mu \mathrm{g}$ leptin) overnight before fractionation with Sephacryl S-200 gel filtration column. Radioactivity of each fraction was counted after gel filtration.

\section{Determination of soluble leptin receptor concentrations}

Soluble leptin receptor concentrations were measured using a commercially available human leptin receptor ELISA kit according to the manufacturer's recommendation (BioVendor Laboratory Medicine Inc., Brno, Czech Republic).

\section{Statistical analysis}

Plasma leptin concentrations were distributed log normal. Differences between groups were evaluated by Student's $t$-test or analysis of variance (ANOVA) with Fisher's least significance difference tests where applicable. Correlations were calculated by Pearson's correlation test. All values were expressed as the mean \pm SEM. $P$ values less than 0.05 were regarded as significant.

\section{Results}

Fig. 1A shows a representative elution pattern from gel filtration with subsequent RIA. The elution pattern has three peaks; the first is around the void volume (Vo), and the third is at the elution position of recombinant leptin (Re). When determined by ELISA, we also found three peaks in the profile of the same eluate. Elution profile of the radioactivity of the same plasma sample after pre-incubation with ${ }^{125}$ I-leptin also has three peaks (Fig. 1B); a fourth peak for degraded free ${ }^{125} \mathrm{I}$ is not shown. The relationship between the first and second peaks remained constant throughout pregnancy in the samples obtained from same patients at different stages of pregnancy. The first 2 peaks were considered as bound leptin and the third, as free leptin. Percent free leptin (\%) was calculated by dividing the leptin content or radioactivity eluted in the third peak (free leptin) by radioactivity in all three peaks. Both methods exhibited similar elution patterns, and the calculated free-to-total leptin ratio (percent free leptin) obtained by different methods were almost the same $(n=4)$. Therefore, in the following study, we employed gel filtration of plasma samples after preincubation with ${ }^{125}$ I-leptin.

Plasma leptin concentrations in pregnant women in the second trimester $(17.4 \pm 3.2 \mathrm{ng} / \mathrm{ml}, \mathrm{n}=5)$ were higher than those in the first trimester $(11.0 \pm 2.8 \mathrm{ng} /$ $\mathrm{ml}, \mathrm{n}=5)$, and remained high in the third trimester (Fig. 2A), as previously reported. However, there was no significant change in the percent free leptin after gel filtration in the first, second and third trimesters (Fig. 2B).

The relationship between percent free leptin and total leptin concentrations or BMI was analyzed in 31 pregnant women in the third trimester. Interestingly, there was no correlation between percent free leptin $(\%)$ and total leptin concentrations $(\mathrm{ng} / \mathrm{ml})(\mathrm{r}=0.006$, $\mathrm{n}=31$, Fig. $3 \mathrm{~A}$ ) or BMI in the third trimester of pregnancy $(r=0.066, n=31$, data not shown). Percent free leptin was virtually constant regardless of varying total leptin concentration or BMI. By contrast, in nonpregnant women, percent free leptin showed a relatively high correlation with total leptin concentration 
A

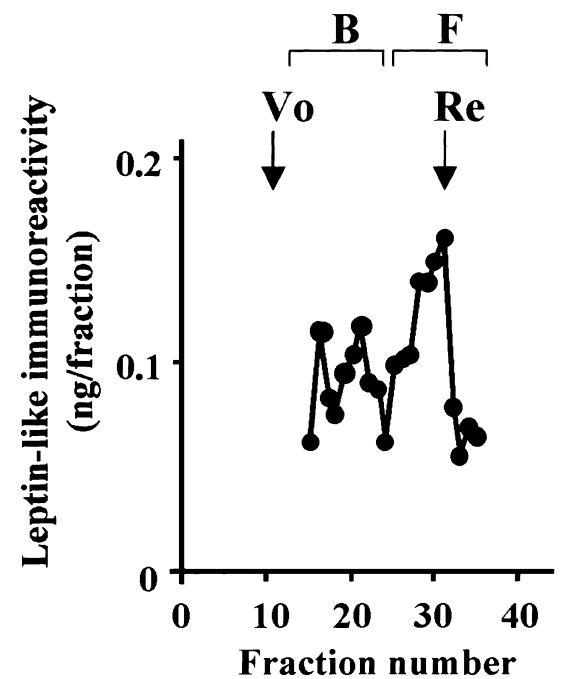

B

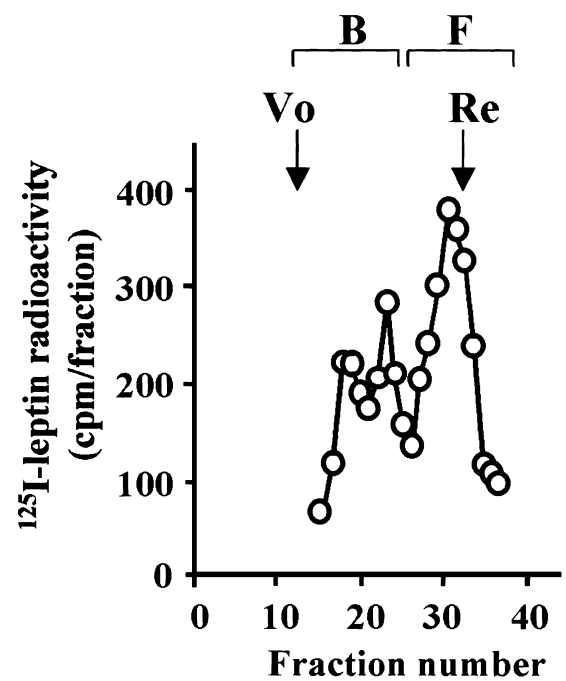

Fig. 1. Representative elution pattern of gel permeation chromatography of leptin-like-immunoreactivity in the plasma from a pregnant woman. The plasma samples demonstrated here is from a second trimester pregnant woman with leptin concentration of $21.1 \mathrm{ng} / \mathrm{ml}$. The procedures were as described in Materials and Methods. Plasma sample without preincubation with ${ }^{125} \mathrm{I}$ labeled leptin (A). Leptin concentration in each fraction was determined by RIA as described in Materials and Methods. Plasma sample incubated with ${ }^{125} \mathrm{I}$ leptin overnight before application to gel permeation chromatography (B). Vo; void volume calibrated with blue dextran. Re; elution position of recombinant leptin. The fourth peak observed in the gel filtration of a plasma pre-incubated with ${ }^{125} \mathrm{I}$ leptin, represents degraded free ${ }^{125} \mathrm{I}$. Therefore, this peak was omitted in the figure. $\mathrm{B}$ and $\mathrm{F}$ indicate bound and free leptin, respectively.

A

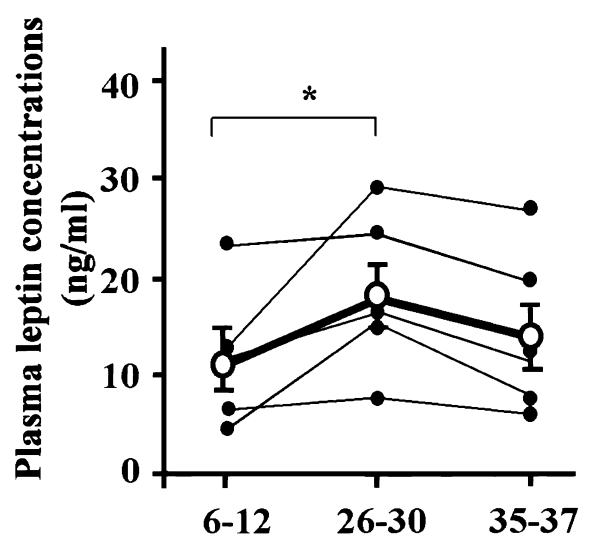

Weeks of gestation
B

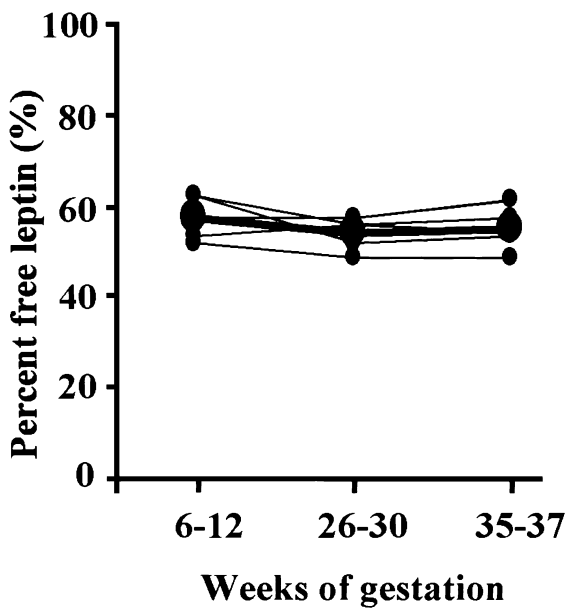

Fig. 2. Changes in plasma leptin concentration (A) and percent free leptin (\%)(B) with the progression of gestational weeks. Values of the same patient are connected with thin lines, and the averages of all the patients are connected with thick lines. ${ }^{*} ; P<0.05$.

$(\mathrm{r}=0.727, P<0.0001, \mathrm{n}=23$, Fig. 3B). Percent free leptin in non-pregnant women also correlated with BMI ( $\mathrm{r}=0.623, P<0.001, \mathrm{n}=23$, data not shown).

Soluble leptin receptor concentrations increased significantly in the second trimester $(45.1 \pm 3.2 \mathrm{U} / \mathrm{ml}$, $\mathrm{n}=5$ ) as compared to those in the first trimester $(23.1 \pm 4.3 \mathrm{U} / \mathrm{m}, \mathrm{n}=5)$, remaining high in the third trimester $(33.6 \pm 5.4 \mathrm{U} / \mathrm{ml}, \mathrm{n}=5$, Fig. 4). Soluble leptin 
A

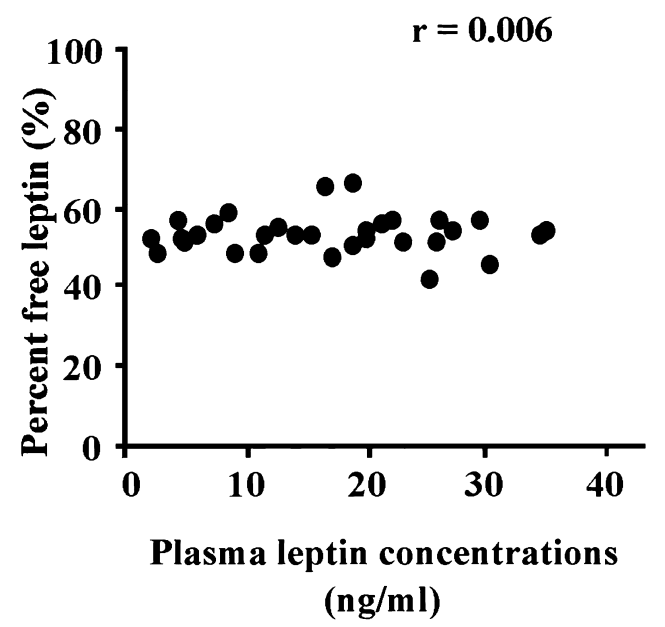

B

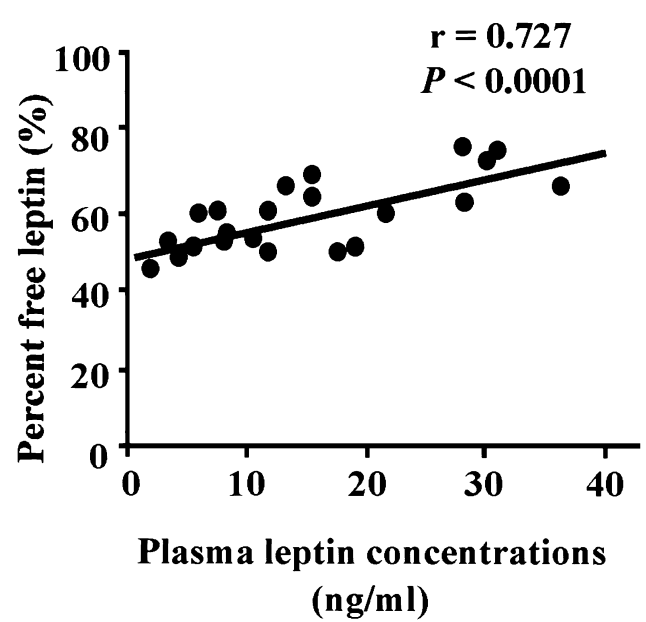

Fig. 3. Correlation between plasma leptin concentrations and percent free leptin (\%) in pregnant women in the third trimester of gestation (A) and in non-pregnant women (B). A: Percent free leptin did not show any significant correlation with total leptin concentration in the plasma of pregnant women in the third trimester. B: Percent free leptin showed a relatively high correlation with total leptin concentration $(\mathrm{r}=0.727, P<0.0001)$ in the plasma of non-pregnant women.

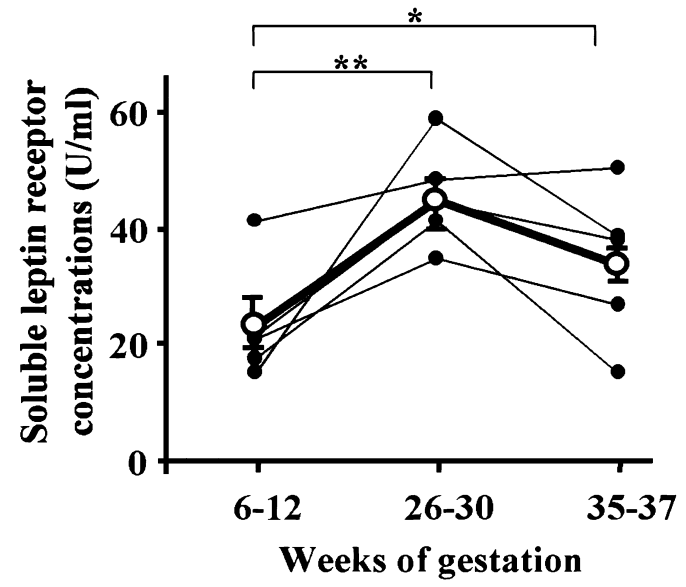

Fig. 4. Changes in the soluble leptin receptor concentrations with the progression of gestational weeks. Values of the same patient are connected with thin lines, and the averages of all the patients are connected with thick lines. ${ }^{*} ; P<0.05, * * ; P<0.005$.

receptor concentrations showed an inverse correlation with plasma leptin concentrations $(\mathrm{r}=-0.493, \mathrm{P}<0.01$, $\mathrm{n}=31$, Fig. 5A) and with BMI $(\mathrm{r}=-0.470, \mathrm{P}<0.01$, $\mathrm{n}=31$, data not shown) in pregnant women in the third trimester of gestation. In contrast, there was no significant correlation between soluble leptin receptor concentrations and plasma leptin concentrations $(\mathrm{r}=-0.295, \mathrm{P}=0.17, \mathrm{n}=23$, Fig. $5 \mathrm{~B})$ nor with BMI in non-pregnant women (data not shown). Soluble leptin receptor in the plasma of pregnant women was recovered $93.1 \%$ and $6.5 \%$ in the first and second peaks of gel filtration, respectively (mean of five experiments). Similar elution patterns were observed for soluble leptin receptor in the plasma of non-pregnant women, with $90.4 \%$ and $9.4 \%$ recovery in the first and second peaks, respectively (mean of five experiments).

\section{Discussion}

The present study confirmed our previous finding and that of others that plasma leptin concentrations increase significantly during pregnancy $[8,19]$. The physiological significance of elevated plasma leptin concentrations during pregnancy is not well understood. The primary role of leptin is a feedback signal to the satiety center. However, such an activity is not beneficial for pregnant women, since they require more nutrients than non-pregnant women do, in order to feed the rapidly growing fetus. In fact, the appetite of pregnant women is not suppressed during pregnancy, suggesting the presence of resistance to the satiety effect of leptin. Another major activity of leptin is to increase insulin sensitivity in peripheral tissues such as muscle, liver, and adipose tissue, and thus leptin stim- 
A

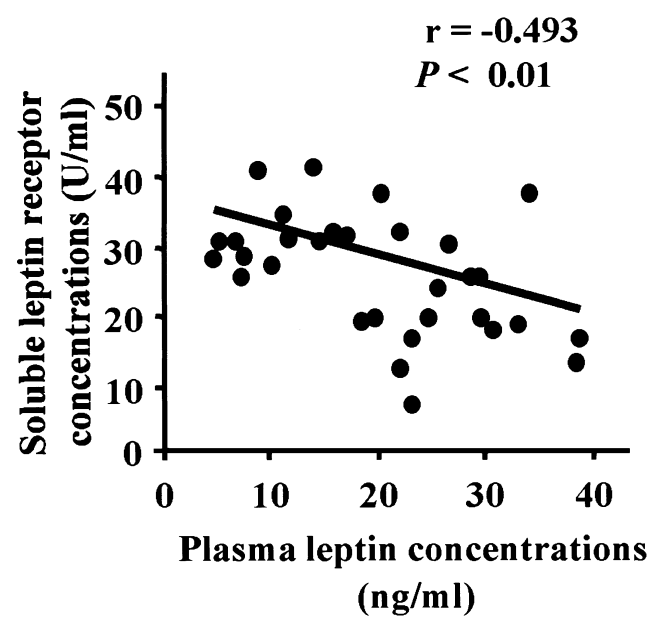

B

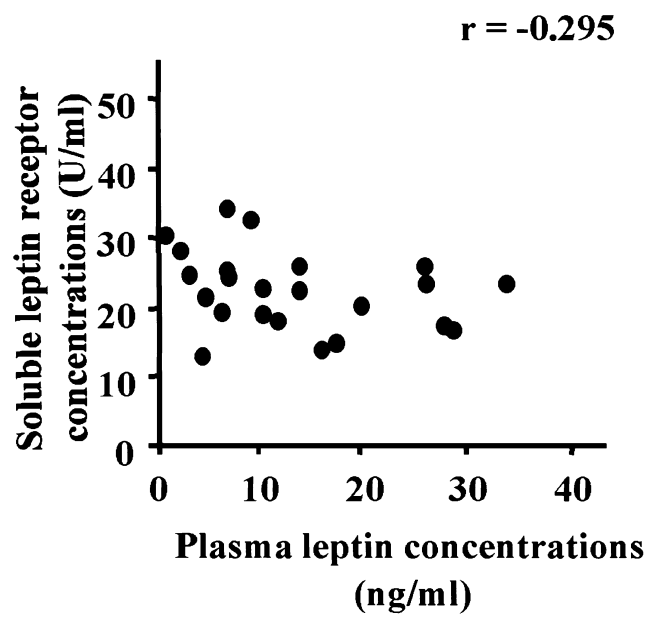

Fig. 5. Correlation between soluble leptin receptor concentrations and plasma leptin concentrations in pregnant women in the third trimester of gestation (A) and in non-pregnant women (B). Soluble leptin receptor concentrations were determined by using a commercially available ELISA kit according to manufacturer's recommendation.

ulates energy utilization in these peripheral tissues [20]. The rapidly growing fetus can be regarded as one of the peripheral tissues since it is solely dependent on the energy supply from the mother. If pregnant women responded to the satiety effect of elevated leptin concentration, the energy supply to the fetus would be drastically attenuated [2]. Elevated maternal leptin concentrations during pregnancy may be beneficial for energy mobilization, and therefore for intrauterine fetal nutrition.

Our elution profile of plasma leptin using Sephacryl S-200 showed 3 apparent peaks in agreement with Lewandowski et al. using Sephadex G-200 [21]. In previous reports, other investigators have demonstrated 2 peaks (bound and free leptin) [12, 15, 22]. These differences are probably due to the larger pore size of gel particles (Sephadex G-200 or Sephacryl S-200) used to separate the larger sized proteins as compared to Sephadex G-100 gel filtration column used in the previous $[12,15,22]$. Gel filtration profiles with $6 \mathrm{M}$ guanidine $\mathrm{HCl}$ was almost identical to that without pretreatment (data not shown). At least 2 kinds of leptin binding proteins $(240$ and $176 \mathrm{kDa})$ have been detected in ligand blotting and immunoblotting [11]. Gel particles with large pore size might separate two different binding proteins into different peaks. Although the entire picture of leptin binding protein including its source has yet to be known, the $\alpha 2$-macroglobulins, OB-BP1 and OB-BP2, were reported to bind to serum leptin $[14,15]$. In mice, placenta secretes leptin binding proteins [13]. However, in humans, cultured placental tissue did not secrete leptin binding protein [18]. Further characterization of leptin binding protein in pregnancy is now under investigation in our laboratory.

In the present study, we did not find any significant change in percent free leptin during pregnancy. Several investigators have attempted to examine free and bound leptin levels during pregnancy. Lewandowski et al. [21] attributed the rise in maternal leptin concentrations between 20-30 weeks to the rise in the bound fraction. Widjaja et al. [22] also reported an increase in bound leptin in the third trimester, whereas Teppa et al. [23] reported an increase in free leptin at term. Although these authors did not calculate free leptin to total leptin ratio in their reports, these findings together suggest that free and bound leptin fractions increase proportionally during pregnancy, with no change of percent free leptin during pregnancy.

In the present study, cross sectional study of pregnant women in the third trimester showed that percent free leptin did not correlate with plasma total leptin concentrations, while in non-pregnant women a significant correlation $(\mathrm{r}=0.727, P<0.0001)$ was observed which is compatible with previous reports $[11,12]$. These findings indicate that pregnant women with elevated leptin concentrations have increased leptin binding capacity in their plasma. In contrast, in non- 
pregnant women, percent free leptin increased as total leptin concentration increased. This suggests that leptin binding capacity is not increased in non-pregnant obese persons and conversely that leptin resistance in the non-pregnant obese person is associated with increased concentration of free leptin. On the other hand, it is possible that increased leptin binding capacity may contribute to the development of the leptin resistance in pregnant women. Thus, the present study suggests that the mechanism for leptin resistance in pregnant women may be different from that in nonpregnant obese women.

Since soluble leptin receptor has binding affinity for leptin, it may function as a leptin binding protein in human circulation. In mice, placenta secretes large amounts of soluble leptin receptor into maternal circulation, which binds to leptin and inhibits leptin clearance from plasma [13]. Thus, in mice, plasma leptin levels increase 20 -fold during pregnancy. In the present study, soluble leptin receptor concentrations in pregnant women in the second trimester were higher than those in the first trimester and remained high in the third trimester. The major part of soluble leptin receptor was eluted in the 1st peak of gel filtration (data not shown). However, the increase in soluble leptin receptor during human pregnancy was not so drastic as compared to that in murine pregnancy. To identify the various binding proteins in pregnancy will be the subject of further studies. It may be related to our preliminary finding that in primary culture, human placental tissue does not secrete soluble leptin receptor (Yura S and Sagawa N; unpublished finding). Soluble leptin receptor concentration in pregnant women in the third trimester of gestation showed a negative correlation with total plasma leptin concentrations and BMI, while no significant correlation was observed in nonpregnant women. This is in contrast with the fact that the concentration of total leptin binding proteins paralleled with that of total leptin, thus maintaining the percent free leptin at a constant level during pregnancy. These findings together suggest that the soluble leptin receptor accounts for a minor portion of the leptin binding capacity in the plasma of third trimester pregnant women, and that some binding proteins other than soluble leptin receptor may play a major role in the increase in leptin binding capacity during human pregnancy. It is also suggested that these binding proteins are regulated by mechanisms different from that for soluble leptin receptor, although further experiments are necessary to confirm these possibilities.

In summary, the present study demonstrated for the first time a constant free-to-total leptin ratio in spite of the increased leptin concentrations with progression of human pregnancy. Thus, percent free leptin was not high in pregnant women with high leptin concentration in late pregnancy. Soluble leptin receptor concentrations also increased during the course of pregnancy, although they did not correlate with total leptin concentrations in the plasma of pregnant women. These findings suggest the possibility that the increased leptin binding capacity other than soluble leptin receptor might contribute to the establishment of leptin resistance during pregnancy.

\section{Acknowledgement}

We thank Drs. M. Yoshida, K. Kakui, D. Korita, and M. Takemura for the discussions. This work is supported in part by Grants-in Aid for Scientific Research from the Ministry of Education, Science, Culture and Sports, Japan (No. 12877262, 13470352, 13557139, 13671707) and grants from the Smoking Research Foundation, Fujiwara Memorial Foundation, and the Kanzawa Medical Research Foundation, Japan.

\section{References}

1. Abrams B, Pickett KE (1999) Maternal nutrition. In: Creasy RK, Resnik R (eds) Maternal-Fetal Medicine. 4th ed, WB Saunders Co., Philadelphia, Pennsylvania, 122-131.

2. Chehab FF (1997) The reproductive side of leptin. Nature Med 3: 952-593.

3. Campfield LA, Smith FJ, Guisez Y, Devos R and Burn P (1995) Recombinant mouse OB protein: Evidence for a peripheral signal linking adiposity and central neural network. Science 269: 546-549.

4. Ogawa Y, Masuzaki H, Hosoda K, Aizawa-Abe M, Suga J, Suda M, Ebihara K, Iwai H, Matsuoka N, Satoh N, Odaka H, Kasuga H, Fujisawa Y, Inoue G, Nishimura H, Yoshimasa Y, Nakao K (1999) Increased glucose metabolism and insulin sensitivity in transgenic skinny mice overexpressing leptin. Diabetes 48: 1822 
1829.

5. Masuzaki H, Ogawa Y, Isse N, Satoh N, Okazaki T, Shigemoto M, Mori K, Tamura N, Hosoda K, Yoshimasa Y (1995) Human obese gene expression. Adipocyte-specific expression and regional differences in the adipose tissue. Diabetes 44: 855-858.

6. Maffei M, Halaas J, Ravussin E, Pratley RE, Lee GH, Zhang Y, Fei H, Kim S, Lallone R, Ranganathan S, Kern PA, Friedman JM (1995) Leptin levels in human and rodents: Measurement of plasma leptin and $\mathrm{o} b$ RNA in obese and weight-reduced subjects. Nature Med 1: 1155-1161.

7. Considine RV, Sinha MK, Heiman ML, Kriauciunas A, Stephens TW, Nyce MR, Ohannesian JP, Marco CC, McKee LJ, Bauer TL, Caro JF (1996) Serum immunoreactive-leptin concentrations in normal-weight and obese humans. N Engl J Med 334: 292-295.

8. Masuzaki H, Ogawa Y, Sagawa N, Hosoda K, Matsumoto T, Mise H, Nishimura H, Yoshimasa Y, Tanaka I, Mori T, Nakao K (1997) Nonadipose tissue production of leptin: Leptin as a novel placenta-derived hormone in humans. Nature Med 3: 1029-1033.

9. Yura S, Sagawa N, Mise H, Mori T, Masuzaki H, Ogawa Y, Nakao K (1998) A positive umbilical venous-arterial difference of leptin level and its rapid decline after birth. Am J Obstet Gynecol 178: 926-931.

10. Linnemann K, Malek A, Sager R, Blum WF, Schneider $\mathrm{H}$, Fusch C (2000) Leptin production and release in the dually in vitro perfused human placenta. J Clin Endocrinol Metab 85: 4298-4301.

11. Houseknecht KL, Mantzoros CS, Kuliawat R, Hadro E, Flier JS, Kahn BB (1996) Evidence for leptin binding to the proteins in serum of rodents and humans: modulation with obesity. Diabetes 45: 1638-1643.

12. Sinha MK, Opentanova I, Ohannesian JP, Kolaczynski JW, Heiman ML, Hale J, Becker GW, Bowsher RR, Stephens TW, Caro JF (1996) Evidence of free and bound leptin in human circulation. Studies in lean and obese subjects and during short-term fasting. J Clin Invest 98: 1277-1282.

13. Gavrilova O, Barr V, Marcus-Samuels B, Reitman M (1997) Hyperleptinemia of pregnancy associated with the appearance of a circulating form of the leptin receptor. J Biol Chem 272: 30546-30551.

14. Birkenmeier G, Kampfer I, Kratzsch J, Schellenberger W (1998) Human leptin forms complexes with alpha 2- macroglobulin which are recognized by the alpha 2macroglobulin receptor/low density lipoprotein receptor-related protein. Eur J Endocrinol 139: 224-230.

15. Patel N, Brinkman-Van der Linden EC, Altmann SW, Gish K, Balasubramanian S, Timans JC, Peterson D, Bell MP, Bazan JF, Varki A, Kastelein RA (1999) OBBP1/Siglec-6 a leptin- and sialic acid-binding protein of the immunoglobulin superfamily. J Biol Chem 274: 22729-22738.

16. Hosoda K, Masuzaki H, Ogawa Y, Miyawaki T, Hiraoka J, Hanaoka I, Yasuno A, Nomura T, Fujisawa Y, Yoshimasa Y, Nishi S, Yamori Y, Nakao K (1996) Development of radioimmunoassay for human leptin. Biochem Biophys Res Commun 221: 234-239.

17. Imagawa $\mathrm{K}$, Matsumoto $\mathrm{Y}$, Numata $\mathrm{Y}$, Morita $\mathrm{A}$, Kikuoka S, Tamaki M, Higashikubo C, Tsuji T, Sasakura K, Teraoka H, Masuzaki H, Hosoda K, Ogawa Y, Nakao K (1998) Development of a sensitive ELISA for human leptin, using monoclonal antibodies. Clinical Chemistry 44: 2165-2171.

18. Yura S, Sagawa N, Ogawa Y, Masuzaki H, Mise H, Matsumoto T, Ebihara K, Fujii S, Nakao K (1998) Augmentation of leptin synthesis and secretion through activation of protein kinases $\mathrm{A}$ and $\mathrm{C}$ in cultured human trophoblastic cells. J Clin Endocrinol Metab 83: 3609-3614.

19. Butte NF, Hopkinson JM, Nicolson MA (1997) Leptin in human reproduction: Serum leptin levels in pregnant and lactating women. J Clin Endocrinol Metab 82: 585-589.

20. Cawthorne MA, Morton NM, Pallett AL, Liu YL, Emilsson V (1998) Peripheral metabolic actions of leptin. Proc Nutr Soc 57: 449-453.

21. Lewandowski K, Horn R, O'Callaghan CJ, Dunlop D, Medley GF, O'Hare P, Brabant G (1999) Free leptin, bound leptin, and soluble leptin receptor in normal and diabetic pregnancies. J Clin Endocrinol Metab 84: 300-306.

22. Widjaja A, Hofmann R, Bruhn J, Muhlen A, Brabant G (2000) Free and bound leptin levels during human pregnancy. Gynecol Endocrinol 14: 264-269.

23. Teppa RJ, Ness RB, Crombleholme WR, Roberts JM (2000) Free leptin is increased in normal pregnancy and further increased in preeclampsia. Metabolism 49: 1043-1048. 